\title{
Thiamine-responsive megaloblastic anemia syndrome
}

INSERM

\section{Source}

INSERM. (1999). Orphanet: an online rare disease and orphan drug data base. Thiamineresponsive megaloblastic anemia syndrome. ORPHA:49827

Thiamine-responsive meg aloblastic anemia (TRMA) is characterized by a triad of megaloblastic anemia, non-type I diabetes mellitus, and sensorineural deafness. 